\title{
STUDY ON THE CHANGE PROCESS AND CHARACTERISTICS OF LAND USE IN THE SHULE RIVER BASIN IN THE RECENT 20 YEARS
}

\author{
ZENG, J. J. ${ }^{1}-\mathrm{LI}, \mathrm{K} . \mathrm{M}^{1}{ }^{*}-\mathrm{CUI}, \mathrm{Y} . \mathrm{Q}^{2}{ }^{2}-\mathrm{CAO}, \mathrm{S} . \mathrm{Z}^{1}{ }^{1}$ \\ ${ }^{1}$ College of Geography and Environmental Engineering, Lanzhou City University, No.1, Jie \\ Fang Road, An Ning District, Lanzhou 730000, China \\ ${ }^{2}$ College of Geography and Environmental Science, Northwest Normal University, Lanzhou \\ 730000, China \\ *Corresponding author \\ e-mail:lkm_wd@126.com; phone: +86-136-0932-3256
}

(Received $27^{\text {th }}$ Sep 2019; accepted $4^{\text {th }}$ Feb 2020)

\begin{abstract}
Based on the LandsatTM/ETM+/OLI remote sensing data (30 m resolution) of the Shule River basin in the past 20 years, the land use data was obtained by interpretation. By using Erdas 9.2 and ArcGIS10.3 software, the land-use types were divided into 6 primary landscape types and 25 secondary landscape types, and the spatial database of watershed land use was established. By using GIS spatial analysis technology, transfer matrix, land use dynamics and many other spatial-temporal statistical analysis methods, the transformation process and temporal and spatial pattern analysis of land-use types in river basin in recent 20 years were carried out, with results showing that: In the past 20 years, different degrees of changes have taken place in land use in the Shule River basin. On the whole, the area of cultivated land, woodland, grassland and urban and rural industrial and mining residents increased, among which grassland increased the most, with an annual increase rate of $0.33 \%$. The area of cultivated land increased, with an annual growth rate of $0.0959 \%$. While water area and unused land decreased, with an annual decline rate of $0.4490 \%$. The decrease of water area was the smallest, with an annual decline rate of $0.0122 \%$. There are obvious differences in the speed and type of change in water area and unused land. The hot spot of land use type transformation in the basin is the middle reaches oasis, mainly Dunhuang, Guazhou and Yumen counties (cities).
\end{abstract}

Keywords: land use, spatial change, transition matrix, characteristic study, Shule River basin

\section{Introduction}

Land use is the most direct form of interaction between human activities and natural environment, and it is also a frontier and hot issue in the study of global change (Liu et al., 2003; Naef et al., 2002; Weng, 2002). The spatiotemporal change of land use can intuitively express the interaction between human activities and natural environment, reflect the relationship between the Earth's environmental system on which Human beings depend for their Survival and the growing production system of mankind (agriculture, industrialization/urbanization, etc.), it will also cause a variety of natural phenomena and ecological process changes (Wu et al., 2006; Guan et al., 2011). Under the background of global change, the change of land use pattern in river basin is gradually strengthening the imbalance and instability of hydrological cycle, thus affecting the controllability, reproducibility, total amount, composition and distribution of water resources. Furthermore, it brings great challenges to the safety of water supply, flood control, water ecology and so on (Ku, 2016; Ning et al., 2018). Therefore, in order to explore the interaction between human activities and natural environment in the inland river basin, we took the Shule River basin as the research area and carried out the analysis 
and study on the transformation process of land-use types and the temporal and spatial pattern in the past 20 years, which provide policy support and technical guarantee for the sustainable and healthy development of the river basin.

\section{Overview of the study area}

The Shule River basin is located in the hinterland of the arid area of northwest China, and is located between $93^{\circ} 22^{\prime}-98^{\circ} 59^{\prime} \mathrm{E}$ and $38^{\circ} 1^{\prime}-42^{\circ} 47^{\prime} \mathrm{N}$. The watershed area is about $1.25 \times 10^{5} \mathrm{~km}^{2}$, which is one of the three inland river basins in Hexi Corridor and one of the seven water rights pilot basins. The watershed location map is shown in Figure 1. The altitude of the river basin is between 914 and $5816 \mathrm{~m}$, lower in the north and higher in the south. It belongs to continental desert climate. As a typical inland river basin, water supply is mainly composed of glacier melt water and mountain precipitation. There are 7 soil types, 31 subclasses and 63 soil genera in the watershed soil. By the end of 2018, the total population of the basin was 524200, and the agricultural population was 221400 , with a natural population growth rate of $4.54 \%$ for many years. At present, the per capita share of water resources is $2933.7 \mathrm{~m}^{3}$ (Yue et al., 2019).

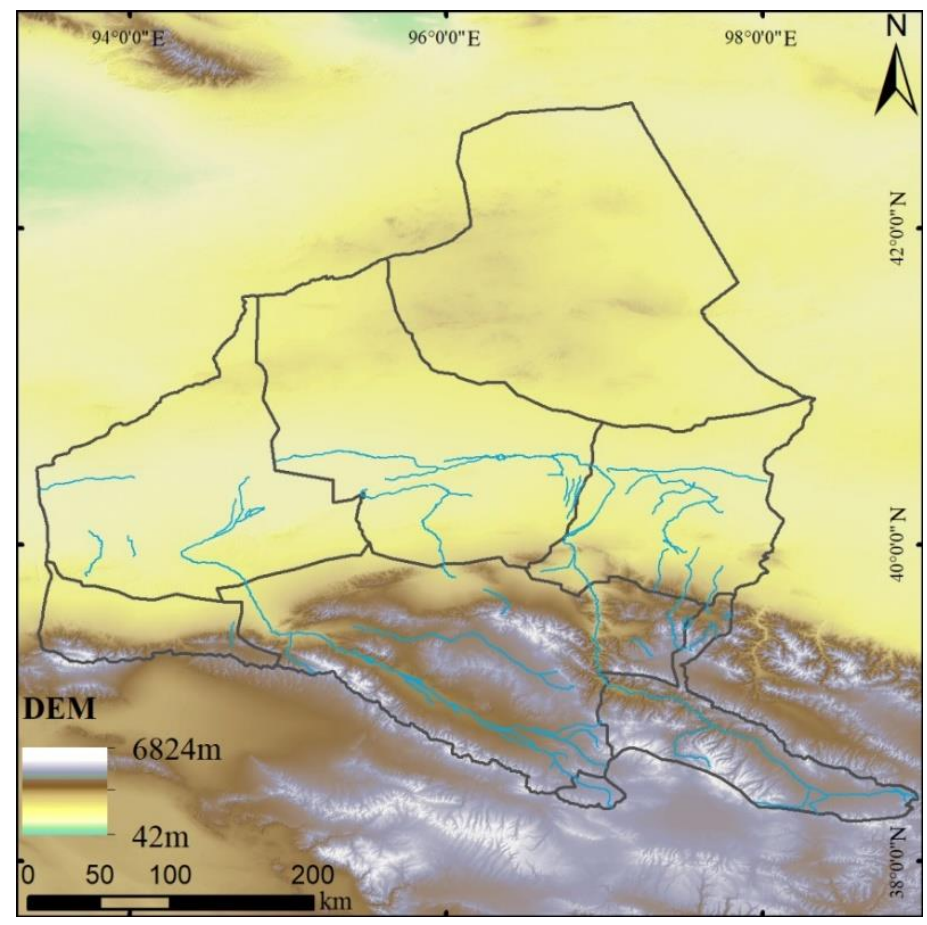

Figure 1. The location of Shule River basin

\section{Research methods}

According to the distribution of rivers and their tributaries, the boundary of the Shule River basin is delineated by using the digital elevation model of the study area in the SWAT hydrological model. The Landsat TM, ETM remote sensing image with spatial resolution of $30 \mathrm{~m}$ in watershed in summer and autumn is selected since in summer and autumn in 1995 and 2015, plants grow best with highest vegetation coverage and it is easy to distinguish from desert, which is conducive to visual interpretation. When extracting for land by information, the $4(\mathrm{R}), 3(\mathrm{G}), 2$ (B) band of TM/ETM+ image is 
combined first to generate a standard false color image and unitedly conversed to Albers projection. Combined with the information of GPS measuring points in the field, geometric correction is carried out. The second is to establish the identification of remote sensing interpretation. First, the interpretation logo is initially established indoors. Then field observation and recording are carried out through GPS positioning and to correct and calibrate the interpretation in turn. The land-using information is extracted again. Adopting the visual interpretation method of human-computer interaction, taking the relevant drawings as a reference, with application of correlation analysis and comprehensive image feature, the boundary of various surface features is to be determined and then to generate the current land-using thematic map by using ArcGIS plug-in. On this basis, the thematic map of land-using change in two time periods is generated by applying ArcGIS spatial overlay analysis function. Finally, the type of surface features is determined while verifying the accuracy of the predicted map through comparing the high-resolution data view provided by GoogleEarth and combining with field observation and experience knowledge. By using Erdas9.2 and ArcGIS10.3 software, the land-use types were divided into 6 primary landscape types and 25 secondary landscape types, and a five-stage land use spatial database of river basin was established.

(1) Single land-use dynamic degree: Quantitative description of the speed of change and the type difference of change, its form of expression is as follows (Chen et al., 2012; Guo et al., 2015; Yang, 2018):

$$
K=\frac{U_{b}-U_{a}}{U_{a}} \times \frac{1}{T}
$$

In the formula, $K$ is the dynamic attitude of land use in the study area; $U_{a}$ and $U_{b}$ are the number of land-use types before and after the change; $T$ is the length of the study period.

(2) The integrate dynamic degree of land use: It is an index to describe the regional difference in the rate of change of land-use types, and reflects the comprehensive impact of human activities on the change of land-use types. Its mathematical model is (Le et al., 2018; Doelman et al., 2018; Bovet et al., 2018; Jin et al., 2013; Huang et al., 2014):

$$
S=\left[\sum_{i=1}^{n} \Delta S_{i-j} / S_{i}\right] \times \frac{1}{T} \times 100 \%
$$

In the formula, $S$ is the comprehensive dynamic attitude of land use, $\Delta S_{i-j}$ is the sum of the area of land-use types before and after conversion, $S_{i}$ is the total area of type $i$ land use, and $t$ is the time of land use change.

\section{Study on the change process and characteristics of land use in Shule River basin \\ Structural change of land-use types in watershed}

As can be seen from Table 1 and Figure 2, between 1995 and 2015: (1) The area of cultivated land, woodland, grassland and urban and rural industrial and mining residents increased, among which grassland increased the most, with an increase of $2069.54 \mathrm{~km}^{2}$. The proportion of grassland increased from $19.88 \%$ in 1995 to $21.54 \%$ in 2015 , with an 
annual increase rate of $0.33 \%$. The area of cultivated land increased by $596.73 \mathrm{~km}^{2}$, and the proportion of cultivated land increased from $0.85 \%$ to $1.33 \%$, with an annual growth rate of $0.0959 \%$. (2) The area of water area and unused land decreased, the area of unused land decreased the most, with a decrease of $2794.74 \mathrm{~km}^{2}$. The proportion of unused land decreased from $78.03 \%$ in 1995 to $75.78 \%$ in 2015, with an annual decline rate of $0.4490 \%$. The decrease of water area was the smallest, with an area of $76.06 \mathrm{~km}^{2}$, and the proportion of grassland decreased from $0.66 \%$ in 1995 to $0.60 \%$ in 2015 , with an annual decline rate of $0.0122 \%$.

Table 1. Land use change in Shule River basin from 1995 to $2015\left(\mathrm{~km}^{2}\right)$

\begin{tabular}{|c|c|c|c|c|c|c|}
\hline \multirow{2}{*}{ Land use type } & \multicolumn{2}{|r|}{1995} & \multicolumn{2}{|r|}{2015} & \multirow{2}{*}{$\begin{array}{l}\text { Area of } \\
\text { change }\end{array}$} & \multirow{2}{*}{$\begin{array}{c}\text { Annual rate } \\
\text { of change }\end{array}$} \\
\hline & Area & Proportion (\%) & Area & Proportion (\%) & & \\
\hline Cultivated land & 1062.00 & 0.85 & 1658.73 & 1.33 & 596.73 & 0.0959 \\
\hline Woodland & 583.35 & 0.47 & 627.02 & 0.50 & 43.67 & 0.0070 \\
\hline Grassland & 24741.53 & 19.88 & 26811.07 & 21.54 & 2069.54 & 0.3325 \\
\hline Water & 819.54 & 0.66 & 743.48 & 0.60 & -76.06 & -0.0122 \\
\hline Urban and rural & 142.67 & 0.11 & 303.54 & 0.24 & 160.87 & 0.0258 \\
\hline Unused land & 97127.90 & 78.03 & 94333.16 & 75.78 & -2794.74 & -0.4490 \\
\hline
\end{tabular}

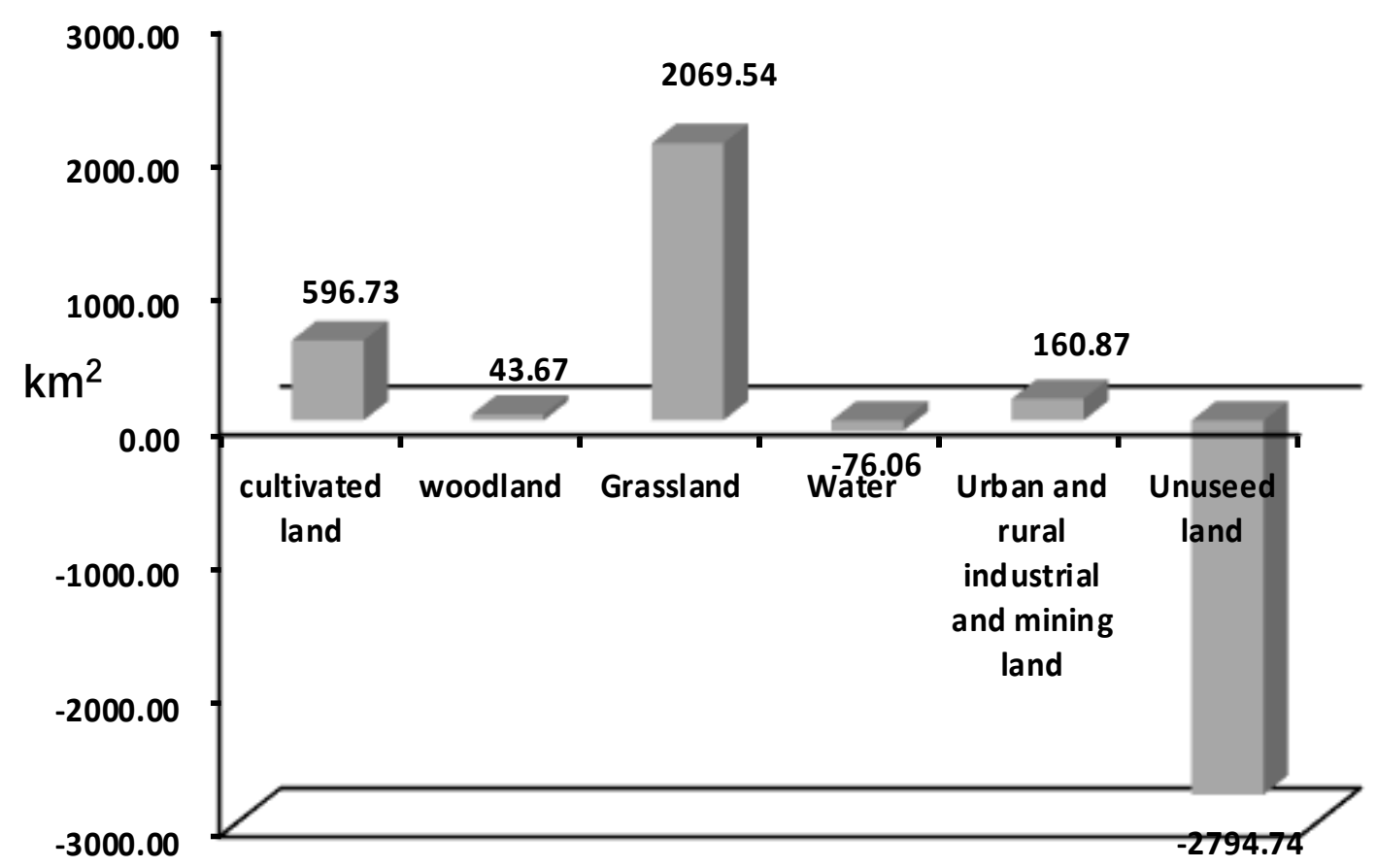

Figure 2. Map of land use change in Shule River basin from 1995 to 2015

Use Equations 1 and 2. Through the dynamic attitude analysis from 1995 to 2015, the dynamic degree of cultivated land, forest land, urban and rural industrial and mining land, water area, grassland and unused land were $0.03 \%, 0.0037 \%, 0.006 \%,-0.0046 \%$, $0.0042 \%$ and $-0.0014 \%$, respectively. It can be seen that there are obvious differences in the speed and type of change in water area and unused land. The spatial distribution pattern of land-use types in Shule River from 1995 to 2015 is shown in Figure 3. 

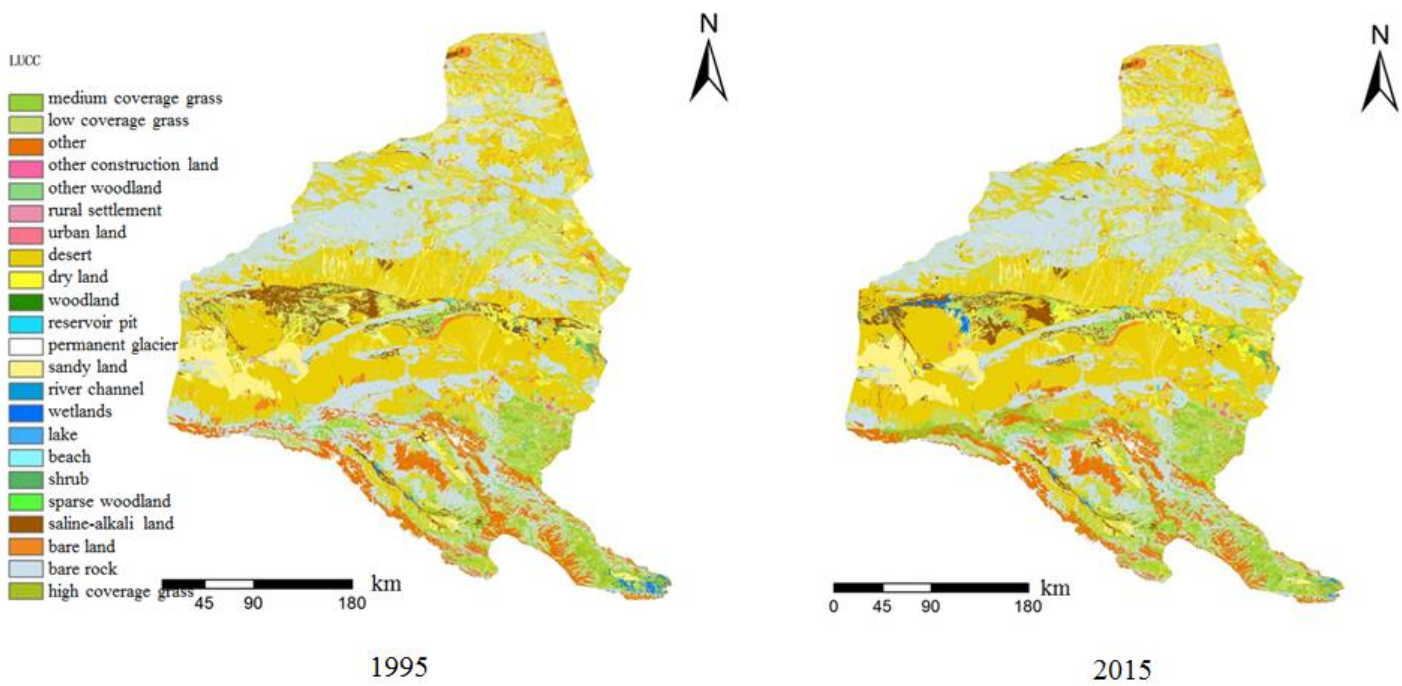

Figure 3. Changes of land-use types in Shule River from 1995 to 2015

From Figure 3, although the land use of the river basin has changed in the past 20 years, the main pattern has not changed. The north is mainly bare rock texture and Gobi; the middle and lower reaches are mainly dry land, grassland and Gobi; there are a lot of saline-alkali land and some grassland between Dunhuang city and Guazhou city, and there are a lot of sandy land in the south and southwest of Dunhuang city. There is bare land, a large area of grassland and permanent glacier snow fields in the upper reaches of the river basin.

\section{Study on transformation of land-use types in river basin}

In order to describe the conversion process of various land-use types from 1995 to 2015 , the transfer matrix of land-use types in each period was calculated by using the function of ArcGIS spatial analysis (Tables 2 and 3), and the map of land use transfer matrix in each period was generated (Mishra et al., 2018; Andraschko et al., 2014; Dai et al., 2012).

Table 2. Transfer matrix of land-use types in Shule River basin from 1995 to $2015\left(\mathrm{~km}^{2}\right)$

\begin{tabular}{c|c|c|c|c|c|c|c}
\hline 1995 & $\begin{array}{c}\text { Cultivated } \\
\text { land }\end{array}$ & Woodland & Grassland & Water & $\begin{array}{c}\text { Urban and } \\
\text { rural }\end{array}$ & $\begin{array}{c}\text { Unused } \\
\text { land }\end{array}$ & Total \\
\hline Cultivated land & 859.70 & 40.44 & 332.52 & 2.47 & 20.69 & 402.70 & 1658.51 \\
Woodland & 9.68 & 445.80 & 76.57 & 0.92 & 0.81 & 93.16 & 626.94 \\
Grassland & 55.20 & 40.63 & 22188.93 & 17.55 & 1.87 & 4492.56 & 26796.75 \\
Water & 7.10 & 0.89 & 35.44 & 615.41 & 0.46 & 84.08 & 743.38 \\
Urban and rural & 72.96 & 1.83 & 22.16 & 0.04 & 115.43 & 91.07 & 303.51 \\
Unused land & 57.00 & 53.55 & 2075.50 & 180.54 & 3.34 & 91918.46 & 94288.39 \\
Total & 1061.63 & 583.14 & 24731.12 & 816.94 & 142.62 & 97082.03 & 124422.4 \\
\hline
\end{tabular}

Table 3. Transfer matrix of different land-use types from 1995 to 2015 (\%)

\begin{tabular}{rl|c|c|c|c|c|c}
\hline 2015 & 1995 & $\begin{array}{c}\text { Cultivated } \\
\text { land }\end{array}$ & Woodland & Grassland & Water & $\begin{array}{c}\text { Urban and } \\
\text { rural }\end{array}$ & Unused land \\
\hline
\end{tabular}




\begin{tabular}{c|c|c|c|c|c|c}
\hline Cultivated land & 51.84 & 2.44 & 20.05 & 0.15 & 1.25 & 24.28 \\
Woodland & 1.54 & 71.11 & 12.21 & 0.15 & 0.13 & 14.86 \\
Grassland & 0.21 & 0.15 & 82.80 & 0.07 & 0.01 & 16.77 \\
Water & 0.95 & 0.12 & 4.77 & 82.79 & 0.06 & 11.31 \\
Urban and rural & 24.04 & 0.60 & 7.30 & 0.01 & 38.03 & 30.01 \\
Unused land & 0.06 & 0.06 & 2.20 & 0.19 & 0.00 & 97.49 \\
\hline
\end{tabular}

The area of cultivated land showed an increasing trend as a whole. The cultivated land area was $1062 \mathrm{~km}^{2}$ in 1995 and $1658 \mathrm{~km}^{2}$ in 2015, which increased $597 \mathrm{~km}^{2}$. Among them, the conversion amount is $798.81 \mathrm{~km}^{2}$, accounting for $0.64 \%$ of the total land area, mainly converted to grassland and unused land. The amount of transfer is $201.94 \mathrm{~km}^{2}$, and the main types of transfer are urban and rural areas, industrial and mining areas, residential land and unused land. The woodland area showed an increasing trend as a whole. The woodland area increased by $44 \mathrm{~km}^{2}$ from $583 \mathrm{~km}^{2}$ in 1995 to $627 \mathrm{~km}^{2}$ in 2015 , of which the transferred area reached $181.14 \mathrm{~km}^{2}$, accounting for $0.15 \%$ of the total land area, and the main types of transfer were unused land and grassland. The amount of transfer was $137.34 \mathrm{~km}^{2}$, and the main types of transfer were unused land and grassland. The grassland area is generally increasing. The grassland area increased by $20693 \mathrm{~km}^{2}$ from $24741 \mathrm{~km}^{2}$ in 1995 to $26811 \mathrm{~km}^{2}$ in 2015 , of which the transferred area reached $4607.82 \mathrm{~km}^{2}$, accounting for $3.70 \%$ of the total land area, and the main types of transfer are unused land and cultivated land; the amount of transfer was $2542.19 \mathrm{~km}^{2}$, and the main types of transfer were unused land and cultivated land. The water area showed a slight decreasing trend. The water area decreased $76 \mathrm{~km}^{2}$ from $820 \mathrm{~km}^{2}$ in 1995 to 743 $\mathrm{km}^{2}$ in 2015 , in which the transfer area reached $127.97 \mathrm{~km}^{2}$, accounting for $0.10 \%$ of the total land area, the main types of transfer were unused land and grassland. The amount of transfer was $201.53 \mathrm{~km}^{2}$, and the main types of transfer were unused land and grassland. The land use of urban and rural, industrial and mining, residents showed an increasing trend. The land area increased $161 \mathrm{~km}^{2}$ from $304 \mathrm{~km}^{2}$ in 1995 to $304 \mathrm{~km}^{2}$ in 2015 , of which the transfer area reached $188.08 \mathrm{~km}^{2}$, accounting for $0.15 \%$ of the total land area, the main types of transfer were unused land and cultivated land; the amount of transfer was $27.19 \mathrm{~km}^{2}$, and the main types of transfer were cultivated land and unused land. Unused land showed a decreasing trend, the unused land area decreased $2794 \mathrm{~km}^{2}$ from $97128 \mathrm{~km}^{2}$ in 1995 to $94333 \mathrm{~km}^{2}$ in 2015 , the transferred area reached $2369.93 \mathrm{~km}^{2}$, accounting for $1.90 \%$ of the total land area. The amount of transfer was $5163.57 \mathrm{~km}^{2}$, and the main types of transfer were grassland and cultivated land.

\section{Conclusion and discussion}

In order to solve the problem of ecological degradation of Shule River, the State Council approved The Comprehensive Plan for Rational Utilization of Water Resources and Ecological Protection in Dunhuang in June 2011. The plan studies and proposes the overall planning idea of "protecting water source in the south, establish oasis in the middle, resist sandstorm in the west, and dredge the Shule River in the north" and the overall planning layout of "coordination of internal and external adjustment, simultaneous protection in the west and dredge in the north, stability of water and oasis, and maintenance of economic and ecological balance". The land use is the most direct manifestation pattern of the interaction between human activities and the natural 
environment. On the other hand, it can also reflect the regional ecological environment problems. In order to further protect the ecological environment of Shule river watershed, and to prevent ecological degradation, the research on the process and characteristics of land use change in Shule River watershed are developed.

The Landsat TM, ETM remote sensing image with spatial resolution of $30 \mathrm{~m}$ in watershed in summer and autumn is selected since in summer and autumn in 1995 and 2015. By using GIS spatial analysis technology, transfer matrix, land use dynamics and a variety of spatio-temporal statistical analysis methods, the transformation process and temporal and spatial pattern analysis of land-use types in river basins in recent 20 years were carried out: In the past 20 years, different degrees of changes have taken place in land use in Shule River basin:

(1) The area of cultivated land, woodland, grassland and urban and rural industrial and mining residents increased, among which grassland increased the most, with an annual increase rate of $0.33 \%$. The area of cultivated land increased, with an annual growth rate of $0.0959 \%$. The area of water area and unused land decreased, with an annual decline rate of $0.4490 \%$. The decrease of water area was the smallest, with an annual decline rate of $0.0122 \%$.

(2) Through the dynamic attitude analysis from 1995 to 2015, the dynamic degree of cultivated land, forest land, urban and rural industrial and mining land, water area, grassland and unused land were $0.03 \%, 0.0037 \%, 0.006 \%,-0.0046 \%, 0.0042 \%$ and $0.0014 \%$, respectively. It can be seen that there are obvious differences in the speed and type of change in water area and unused land.

(3) Although the land use of the river basin has changed in the past 20 years, the main pattern has not changed. The north is mainly bare rock texture and Gobi; the middle and lower reaches are mainly dry land, grassland and Gobi; there are a lot of saline-alkali land and some grassland between Dunhuang city and Guazhou city, and there are a lot of sandy land in the south and southwest of Dunhuang city. There are is bare land, a large area of grassland and permanent glacier snow fields in the upper reaches of the river basin.

Acknowledgments. This research was supported by Doctor research launch aid of Lanzhou City University in 2019 (LZCU-BS2019-20), the National Natural Science Foundation of china (grant nos. 41661014), the National Natural Science Foundation of Gansu (grant nos. 18JR3RA221).

\section{REFERENCES}

[1] Andraschko, F., Sirker, J. (2014): Dynamical quantum phase transitions and the Loschmidt echo: a transfer matrix approach. - Physical Review B 89(12): 125120.

[2] Bovet, J., Reese, M., Köck, W. (2018): Taming expansive land use dynamics - sustainable land use regulation and urban sprawl in a comparative perspective. - Land Use Policy 77: 837-845.

[3] Chen, S., Liu, W., Qin, X., Liu, Y., Zhang, T., Chen, K., Hu, F., Ren, J., Qin, D. (2012): Response characteristics of vegetation and soil environment to permafrost degradation in the upstream regions of the Shule River Basin. - Environmental Research Letters 7(4): 045406.

[4] Dai, H., Wang, L., Qian, Q., Gan, J. (2012): Vibration analysis of three-dimensional pipes conveying fluid with consideration of steady combined force by transfer matrix method. Applied Mathematics and Computation 219(5): 2453-2464.

[5] Doelman, J., Stehfest, E., Tabeau, A., Meijl, H., Lassaletta, L., Gernaat, D., Hermans, K., Daioglou, V., Biemans, H., Sluis, S., Vuuren, D. (2018): Exploring SSP land-use dynamics 
using the IMAGE model: regional and gridded scenarios of land-use change and land-based climate change mitigation. - Global Environmental Change 48: 119-135.

[6] Guan, D., Li, H., Inohae, T., Su, W., Nagaie, T., Hokao, K. (2011): Modeling urban land use change by the integration of cellular automaton and Markov model. - Ecological Modelling 222(20-22): 3761-3772.

[7] Guo, X., Feng, Q., Liu, W., Li, Z., Wen, X., Si, J., Xi, H., Guo, R. (2015): Stable isotopic and geochemical identification of groundwater evolution and recharge sources in the arid Shule River Basin of Northwestern China. - Hydrological Processes 29(22): 4703-4718.

[8] Huang, J., Yang, X., Cheng, G., Wang, S. (2014): A comprehensive eco-efficiency model and dynamics of regional eco-efficiency in China. - Journal of Cleaner Production 67: 228238.

[9] Jin, S., Yang, L., Danielson, P., Homer, C., Fry, J., Xian, G. (2013): A comprehensive change detection method for updating the National Land Cover Database to circa 2011. Remote Sensing of Environment 132: 159-175.

[10] $\mathrm{Ku}, \mathrm{C}$. A. (2016): Incorporating spatial regression model into cellular automata for simulating land use change. - Applied Geography 69: 1-9.

[11] Le, T., Bregt, A., van Halsema, G. E., Petra J. G., Hellegers, J., Nguyen, L. (2018): Interplay between land-use dynamics and changes in hydrological regime in the Vietnamese Mekong Delta. - Land Use Policy 73: 269-280.

[12] Liu, J., Liu, M., Zhuang, D., Zhang, Z., Deng, X. (2003): Study on spatial pattern of landuse change in China during 1995-2000. - Science in China Series D: Earth Sciences 46(4): 373-384.

[13] Mishra, P., Blaum, K., George, S., Grieser, A. W. (2018): Transfer matrix calculation for ion optical elements using real fields. - Nuclear Instruments and Methods in Physics Research Section A: Accelerators, Spectrometers, Detectors and Associated Equipment 885: 124-133.

[14] Naef, F., Scherrer, S., Weiler, M. (2002): A process-based assessment of the potential to reduce flood runoff by land use change. - Journal of Hydrology 267(1-2): 74-79.

[15] Ning, J., Liu, J., Kuang, W., Xu, X., Zhang, S., Yan, C., Li, R., Wu, S., Hu, Y., Du, G., Chi, W., Pan, T., Ning, J. (2018): Spatiotemporal patterns and characteristics of land-use change in China during 2010-2015. - Journal of Geographical Sciences 28(5): 547-562.

[16] Weng, Q. (2002): Land use change analysis in the Zhujiang Delta of China using satellite remote sensing, GIS and stochastic modelling. - Journal of Environmental Management 64(3): 273-284.

[17] Wu, Q., Li, H., Wang, R., Paulussen, J., He, Y., Wang, M., Wang, B., Wang, Z. (2006): Monitoring and predicting land use change in Beijing using remote sensing and GIS. Landscape and Urban Planning 78(4): 322-333.

[18] Yang, J., Ji, Z., Chen, D., Chen, D., Kang, S., Fu, C., Duan, K., Shen, M. (2018): Improved land use and leaf area index enhances WRF-3DVAR satellite radiance assimilation: a case study focusing on rainfall simulation in the Shule River basin during July 2013. - Advances in Atmospheric Sciences 35(6): 628-644.

[19] Yue, D., Chen, G., Zou, M., Guo, X., Zhou, Y., Li, K., Wang, D., Guo, J., Zeng, J. (2019): Biocapacity and ecological water demand in Shule River basin over the past 20 years. Acta Ecologica Sinica 39(14): 5178-5187. 